\title{
Investigating Causal Relations between the GDP Cycle and Unemployment: Data from Finland
}

\author{
A. Khalik Salman ${ }^{1} \&$ Ghazi Shukur ${ }^{2,3}$ \\ ${ }^{1}$ Department of Economics Sciences and Law, Mid-Sweden University, Sweden \\ ${ }^{2}$ Department of Economics and Statistics, Linnaeus University, Växjö, Sweden \\ ${ }^{3}$ Department of Economics, Finance, Statistics and Informatics, Jönköping University, Jönköping, Sweden \\ Correspondence: A. Khalik Salman, Department of Economics Sciences and Law, Mid-Sweden University, SE \\ 831 25, Östersund, Sweden.Tel: 46-63-165-794. E-mail: khalik.salman@miun.se
}

Received: December 4, 2013

Accepted: January 26, 2014

Online Published: March 25, 2014

doi:10.5539/ijef.v6n4p118

URL: http://dx.doi.org/10.5539/ijef.v6n4p118

\begin{abstract}
This paper investigates the causal relationship between two macroeconomic variables, the gross domestic product (GDP) cycle and unemployment, in Finland. This has been done using the vector autoregressive (VAR) model for the period Q1 1995 to Q2 2011. The goal of this study is to gather further evidence for the relationship between the GDP cycle and total, male and female unemployment individually, with special reference to Finland which is a member state of the EU, and has been part of European monetary union, since 1995. The relationship has been investigated using the Granger-causality test in accordance with Okun's (1962) formula. The empirical facts mostly indicate the existence of a uni-directional causal relationship from the GDP cycle to unemployment. This pattern is not found to be significant when using the model for unemployment in women however. The coefficients of unemployment, total, male and female, are abstracted from the Okun's coefficient and found to be around -4 per cent total, male and female unemployment individually, -5 per cent and -1 per cent respectively. These results also have important implications for determining macroeconomic and labor-market policy.
\end{abstract}

Keywords: granger-causality, GDP cycle, unemployment, VAR model

\section{Introduction}

One application of ad hoc distributed lag models is to provide evidence of the direction of causality in economic relationships. Such a test is of interest when variables are related but we do not know the direction of causality between them. Most economists think that a decline in GDP stimulates unemployment but not the opposite. So is this the case? One approach to the problem is to test for what is called 'Granger causality'. This approach is useful because it allows us to know which variable affects or 'leads' the other one and, as we shall see, leading variables are very useful for forecasting purposes.

Despite the value of Granger causality, we should not let ourselves be lured into thinking that it allows us to prove economic causality in any rigorous way. If one variable precedes another, we cannot be sure that the first variable causes the other to change.

Using Granger causality naturally leads us to consider models with several equations and the topic of VAR models. Before estimating for causality, we need to first define the proper order of the VAR model. The variables included in such a model are either assumed to be stationary or non-stationary. If they are non-stationary and integrated of the same order then we have to test whether they are cointegrated before conducting any test for causality. For this purpose we applied the Johansen (1988) test for cointegration before conducting causality tests The appendices to this study include all results with respect to the cointegration tests and the estimations of the equations, together with the respective diagnostic tests that show the appropriateness of the selected models.

In this study we consider data from Finland for the period Q1 1995 to Q2 2011, which covers period of major change in Finnish employment-protection law and in unemployment benefit. It was also a time when financial crisis in Finland caused a shortfall in GDP and a rise in unemployment. Our current investigation also tries to emphasize the effects of the GDP cycle on unemployment in a country which has been a part of European monetary union since 1995. The combination of a decline in productivity and working hours implies that movements in unemployment are smaller than movements in GDP. The relationship between changes in 
economic growth and unemployment is known as 'Okun's law'. Formulated by Okun in 1962, the law stated that a shortfall in GDP of 3 per cent relative to normal growth produces a 1 per cent increase in unemployment; a more accurate description of the current relationship is 2 to 1 .

The important questions are as follows:

(1) Does Okun's law help to predict potential unemployment even in European Union countries and countries which are part of the European monetary union?

(2) Do the rates of unemployment (total, male and female) tend to be equal during periods of recession in Finland? If men and women have similar opportunities, then we suppose that the estimated parameters for male and female unemployment to be similar.

In this context, numerous studies in the literature have expressed the formula for Okun's hypothesis in many different ways. Most of these studies have used the variable in difference forms, which results in damage to the long-term information within and between the macroeconomic variables included in the models. In this study, we avoid this situation by including the variables in level after testing for cointegration and finding them to be cointegrated.

The data used in estimating the GDP cycle and unemployment are described in detail in the Organisation for Economic Co-operation and Development (OECD) database (2011). In brief, the data are quarterly and from period Q1 1995 to Q2 2011. We specify VAR models with different lags, i.e. VAR (3) for total and male unemployment and two lag lengths for female unemployment, i.e. $\operatorname{VAR}(2)$.

In this study, we use a different approach than that used in previous studies and we analyze more variables by including separate analysis of male and female unemployment. In addition, previous empirical studies have not applied the Granger-causality test to investigate the relationship between these two macro variables in Finland. The majority of previous empirical papers estimated the relationship using total unemployment only. Our work may also contribute to the literature on applied economics and labor economics by using the Granger-test methodology to investigate the relationship between the GDP cycle and unemployment categories.

The rest of the paper is designed in the following way. In section 2 we set out the previous empirical studies. In section 3 we offer the data and outline the model specification and the methodology of study. The tests and estimated results are described in section 4. A final section, 5, includes our conclusions.

\section{Previous Empirical Studies}

Okun's law, formulated in 1962, stated that a shortfall in GDP of 3 per cent relative to normal growth produces a 1 per cent increase in unemployment; a more accurate description of the current relationship is 2 to 1 (Note 1).

Turning to the empirical facts of the GDP cycle, one fact reported is that real wages are not strongly correlated with GDP over the cycle, and, in particular, there is no strong indication that an increase in GDP is connected with an increase in real wages. At the same time there is a clear indication that increases in GDP are accompanied by decreases in reported unemployment in USA and Denmark (Sorensen \& Whitta, 2010). This relationship is both important and useful. It shows, for instance, that at a constant rate of unemployment, economic growth in USA is around 3 per cent per year, while for Denmark the corresponding intersection is just above 2 per cent. A one-time increase in GDP of 3 per cent reduces unemployment by around 2 per cent in Denmark and by slightly less in the USA. This empirical study illustrates by graphical correlation technique how unemployment responds to total economic activity, (see also Sorensen \& Whitta, 2010).

The empirical facts also showed that the GDP cycle has substantial consequences for unemployment. These are anticipated to differ between countries in the EU and the USA. For instance, the Okun coefficient will be completely different in Finland than it is in Sweden and the USA. This result is to be expected, because these differences are mostly due to the higher growth in the labor force in the USA, and because most European countries, and especially Scandinavian countries, have different unemployment benefits legislation, which helps to vary periods of unemployment (Note 2).

Numerous empirical studies after Okun have shown that the GDP cycle affects employment. An empirical study of data for East Asia and Mexico, Fallon and Lucas (2002), used time-series data for the 1990s to estimate the relationship between GDP and employment. The study showed that employment declined by more than GDP and even increased in some periods. Aranki, Friberg and Sjödin (2010) used Swedish data, which appeared to show that the relationship between the recession and unemployment has weakened and varied. The study used rolling regression technique for the different periods. 
More facts in support of the negative association between unemployment and the GDP cycle in the USA can be found in Prachowny (1993), which also supports the view that Okun's hypothesis can help to predict upcoming intensity of unemployment. Another study by Lee (2000), however, showed that the coefficients of the effects of GDP on unemployment differ noticeably across countries, probably because of the inflexible situation of the labor markets, see also Cuaresma (2003). Padalino and Vivarelli (1997) noticed a significant association between GDP and employment for the majority of the developed countries (i.e., the G7).

In addition, using data for the USA, Canada, Europe and Japan, Moosa (1997) tried to measure the association between total economic growth and employment using a seemingly unrelated regression (SUR) model. The results from this paper indicated that the reaction of employment rate to GDP cycle was larger in the USA and Canada than in other developed countries, (see also Silvapulle, Moosa, \& Silvapulle, 2004). In this context, Knotek (2007) examined the effect of the US slowdown in growth on unemployment by means of time-series data from the period 1948 to 2006 and found similarities between Okun's estimation and his study by using a rolling regressions method. (See also International Monetary Fund, 2010).

On the other hand, the model proposed by Piacentini and Pini (1998) did not find any actual effect of economic growth on employment. Hence, unemployment can in fact occur even in the midst of economic growth. Moreover, Pianta, Evangelista and Perani (1996), studying 36 sectors of manufacturing among the G7 group, found that employment does need to positively move together with economic growth, but did not show that economic growth has an important effect on employment.

A more recent study of Swedish data, Salman (2012), used quarterly time-series data for the period Q1 1995 to Q2 2011 to estimate the association between output and unemployment gender using the Granger-causality test technique. The author showed that unemployment (total, male and female) responded differently to the fluctuations of the GDP coefficient than it did to Okun's coefficient. The study also showed that coefficient to be approximately 8 per cent for total, male and female unemployment in Sweden. Salman found the coefficients of all the unemployment percentage categories to be significantly negative.

Since the relationship between the economic growth and the annual rate of unemployment differs between countries, it is thought that the Okun coefficients are instable and change over time. These differences are mainly due to a higher growth of the technological infrastructure and innovation, the replacement rate, reform of labor-market policies and institutions, fiscal resources at government disposal, international competition, labor law and policy (Black, 1987). Researchers have shown that changes in GDP have substantial consequences for unemployment which are likely to be different in the USA than in other industrialized countries, Lee (2000). Nevertheless, it seems now that Okun's law might in fact be a fairly useful tool for comparisons and over time and across countries.

Therefore, we can conclude that the previous studies have emphasized that Okun's coefficient depends on the period of the studies and the legal stipulations for employment security in the country studied. Therefore, the coefficient is expected to be smaller where the country offers its workers a higher degree of employment protection compared with that in other countries, Altig, Fitzgerald and Rupert (2002) and Knotek (2007).

In this paper, our main purpose is to add to existing empirical studies by measuring the association between GDP and unemployment in Finland. Numerous studies on this topic have shown that such an association seems to have been undermined in recent years, both in Finland and in other industrialized countries, including the Scandinavian countries. This study is important for Finland for the following reasons.

(i) Finland provides an interesting context for this study because of its situation as an economy in transition in the time period under study, and because it is now equivalent in place to the most industrial countries in Europe.

(ii) Finland has used new policies on international trade and the labor market and has become more dependent on technological progress, moving towards increased international competition in all economic activity. Thus, one of the innovations of our paper is its consideration of the degree of association between the GDP cycle and annual rate of unemployment during Finland's evolution and development of its new technological infrastructure. In addition, the data used cover three major recession periods in Finland, which contributed to shortfalls in GDP. Additionally, Finland was a member of the European Union and European monetary union during the period of the study.

(iii) The Granger causality of the relation between the GDP cycle and unemployment, and the Johansen (1988) methodology of cointegration, have not been applied in previous papers, despite their broad attractiveness. The contribution of our study to the literature of applied macroeconometrics models and the economics of the labor market is its investigation of the causality between the GDP cycle and unemployment. 


\section{Data and Methodology}

The data used in this study was extracted from the database of the OECD (2011) during the period Q1 1995 to Q2 2011. The GDP cycle variable is GDP measured in constant price year 2000. When testing for causality here we want to see if the first variable precedes the other or the opposite, or whether both cause each other simultaneously. In this paper, when we test whether the GDP cycle 'Granger causes' unemployment it is to observe how much of the current values of unemployment are explained by previous values of the GDP cycle and vice versa. However, we conduct the test by first estimating the next VAR model and then applying the test:

$$
\begin{gathered}
U n_{t}=a_{0}+\sum_{i=1}^{k} a_{i} U n_{t-i}+\sum_{i=1}^{k} b_{i} \text { GDPcycle }_{t-i}+e_{1 t} \\
\text { GDPcycle }_{t}=c_{0}+\sum_{i=1}^{k} c_{i} U n_{t-i}+\sum_{i=1}^{k} f_{i} \text { GDPcycle }_{t-i}+e_{2 t}
\end{gathered}
$$

Where:

$\mathrm{Un}=$ percentage change in unemployment, $\mathrm{t} / \mathrm{t}-4$, which is not seasonally adjusted;

$\mathrm{GDP}=$ real GDP at the base-period price 2000;

$e_{1 t}$ and $e_{2 t}$ are random errors with means equal to zero and invariable variances.

However, since unemployment and the GDP cycle are found to be non-stationary and have stochastic trends (augmented Dickey-Fuller (ADF) test (Dickey \& Fuller, 1979; 1981)), we checked whether they are cointegrated by applying the Johansen (1988) maximum likelihood before testing for causality. The Dickey-Fuller test results are summarized in Tables A1 to A4 in the Appendix. To specify the order of the lags in the equations above we use Schwarz (1978) information criteria (SIC). According to the SIC, the order of the VAR models, $k$, has been set as equal to 3, i.e., VAR (3), for total unemployment and male unemployment, while the SIC indicated that the order 2, i.e. VAR (2), was proper for female unemployment. Using a battery of diagnostic tests these models have been shown to be well specified. The outputs of the tests are presented in Tables C1 to C3, in the Appendix. A Granger-causality F-test is then conducted to test for the causal relationship between the variables in the VAR models. If all the values of $b_{i}$ are all together not statistically different from zero, we can claim that the GDP cycle does not cause unemployment. In the same way, if all the values of $c_{i}$ are all together not statistically different from zero, we can claim that unemployment does not cause the GDP cycle.

The diagnostic tests we applied are: the White (1980) test for heteroskedasticity; the Breusch (1978) and Godfrey (1978) test for autocorrelations in the residuals; the Engle (1982) Lagrange multiplier (LM) tests for autoregressive conditional heteroskedasticity $(\mathrm{ARCH})$ errors; the regressive equation specification error (RESET) (1969) test for omitted variables; the Jarque and Bera (1987) test for normality; and the cumulative sum (CUSUM) test for parameter stability. The results of these tests are given in Tables C1 to C3 in the Appendix. Processing in this manner one can avoid less adequate models, which could lead to enormously misleading results and inferences. Overall though, the estimation results and the results from the diagnostic tests have shown that the estimated coefficients are sufficiently representative.

\section{Results}

This section presents results from Granger-causality testing of models (1) and (2) for total unemployment and male unemployment, using the VAR(3) specification. The VAR(2) model is used for the female unemployment. These results are presented in the following Tables 1 to 3, respectively. The test results for total unemployment and male unemployment are for the period Q1 1995 to Q2 2011. Looking at the p-value for the null hypothesis, at the 5 per cent significant level, it is possible to conclude that the GDP cycle does Granger cause total unemployment and the male unemployment. However, for the same period, the p-value for the null hypothesis, at any conventional significance level, indicates that total unemployment and the male unemployment do not Granger cause GDP cycle. Thus, causality is uni-directional: GDP affects total unemployment and male unemployment but not the reverse. However, this pattern could not be found for female unemployment in Table 3. 
Table 1. Results for total unemployment (TUE), VAR(3)

\begin{tabular}{ll}
\hline Null hypothesis & P-value \\
\hline No Granger causality from TUE to GDP cycle & 0.050 \\
No Granger causality from GDP cycle to TUE & 0.009 \\
\hline
\end{tabular}

Note. These results are taken from Table A1 in the Appendix of this study.

Table 2. Results for male unemployment (MUE), VAR(3)

\begin{tabular}{ll}
\hline Null hypothesis & P-value \\
\hline No Granger causality from MUE to GDP cycle & 0.053 \\
No Granger causality from GDP cycle to MUE & 0.002 \\
\hline
\end{tabular}

Note. These results are taken from Table A2 in the Appendix of this study.

Table 3. Results for female unemployment (FUE), VAR (2)

\begin{tabular}{ll}
\hline Null hypothesis & P-value \\
\hline No Granger causality from FUE to GDP cycle & 0.054 \\
No Granger causality from GDP cycle to FUE & 0.390 \\
\hline
\end{tabular}

Note. These results are taken from Table A3 in the Appendix of this study.

The results presented in this study suggest a temporary lag, rather than a fundamental change in the relationship between GDP cycle and unemployment. The regression results show that Finland has coefficients for total, and male and female unemployment, with respect to the first lag of the GDP, which are approximately $-0.4,-0.5$ and -0.1 per cent respectively during the period studied, Q1 1995 to Q2 2011. Results for these coefficients are summarized in Table 4.

Table 4. The cointegration regression results for the GDP cycle and unemployment categories

\begin{tabular}{lllll}
\hline Unemployment categories & Coefficients & SE & T-statistic & P-value \\
\hline Total unemployment (t-1) & -0.04 & 0.011 & -3.137 & 0.000 \\
Male unemployment & -0.05 & 0.0143 & -3.8429 & 0.003 \\
Female unemployment & -0.01 & 0.008 & -1.326 & 0.173 \\
\hline
\end{tabular}

Note: This table is derived from Tables B1 to B3 and Tables C1 to C3.

Our findings demonstrate an obviously significant and negative association between the GDP cycle and the unemployment rate categories (except female unemployment). The results from the cointegration regression indicate that the current economic situation in Finland can be modelled by lagged GDP, although only the lag number one indicates significant and negative relation to unemployment. For female unemployment the results was negative but not significantly related to the GDP cycle.

\section{Conclusion}

The statistical results for the VAR Granger-causality tests indicated that only the GDP cycle Granger causes unemployment. However, unemployment does not Granger cause the GDP cycle. Based on data from Finland, the modeling results show growth in GDP and the absolute change in unemployment (total and male) have a negative relationship. The results also indicate that the total unemployment and male unemployment coefficients are significant and negative. However, the results confirm that the unemployment coefficient is diverted from Okun's coefficient and is not strongly correlated with GDP over the cycle, probably due to special circumstances in Finland i.e. the replacement rate as regards female unemployment and labor-market regulation. In particular, the changes in female employment were less receptive to GDP over the cycle, which might be because of the high replacement rate and other social payments that also cover additional revenue expenses for jobless women who 
have little track record in the labor force. In nearly all europe, the replacement rate at the beginning of a spell of unemployment is usually higher for a couple with two children than for someone who is single. For instance in Finland, where the initial replacement rate is 82 per cent, the unemployed have little incentive to seek regular work. The replacement rates for long-term unemployed are lowest in Italy, Greece and the USA and highest in the Scandinavian countries (except Norway), Slovakia, the Netherlands, Austria and Germany (Note 3).

There is debate about whether the European social model is one of the causes of higher unemployment in continental Europe, when compared with models in the UK or the USA. According to some labor economists, there is no doubt that high levels of unemployment insurance, employment protection and high minimum wages are partly responsible for the high unemployment rates in many European countries. Yet, it has also been argued that labor-market rigidities are not necessarily associated with high unemployment. Although it is true that, on average, countries with higher labor-market rigidities have higher unemployment rates, it is also true that some countries with low unemployment rates do have high minimum wages. The most notable case in Europe is Denmark. The peculiarity of the Danish system is that, since the early 1980s it has combined generous unemployment benefits with an effective system for helping workers find jobs: the result is a low unemployment rate, one of the lowest in Europe.

The results of our study confirm that the GDP cycle over the period has a negative and significant influence on total unemployment and male unemployment rate, approximately $-0.4,-0.5$, in that order. In this context, the empirical evidence indicates that the recession is a major cause of instability for total unemployment and male unemployment in this study, while it appears that female unemployment is lower than those of the total and male unemployment, perhaps because of Finland's stricter replacement rate for women, which makes it more difficult to fire women from jobs during a shortfall in GDP, and to hire during a recovery. Therefore, labor legislation should lead to a lower-scale elasticity of layoffs of women with respect to changes in GDP. Moreover, employment-protection legislation allows women to stay at home with children and treat the period at home as working time during periods of a shortfall in GDP. Firms may as well foresee the difficulty in recruiting capable and qualified employees when the GDP goes up. In addition, laying off workers takes time during which period the productivity of the firm may fall.

Overall, this study showed lower coefficients for Finnish unemployment compared with those in previous Scandinavian studies, this is due to the differences in Finland's labor-market legislation and the replacement rate regulation in Finland's labor market (Note 4). Furthermore, the statistical modeling of this study indicates that the estimated coefficients of the economic growth with respect to the absolute change in unemployment for both men and women are not similar. According to the results from the model, estimates show that the proportion of employed men decreased somewhat, and the proportion of unemployed men increased, during the period. It suggests that as regards the labor market, Finnish policymakers used different policies for male and female employees or applied them differently or that there was not equality of opportunity during the slowdown period. In any case, the evidence shown here has useful implications and importance for deciding labour-market policy.

\section{References}

Aliard, G. (2005). Measuring job security over time: In search of a historical indicator foe EPL. IE working paper WP05-17, Madrid. Retrieved from www.cesifo-group.de/portal/page/portal/ifoHome/a-winfo/d3ilv

Altig, D., Fitzgerald, T., \& Rupert, P. (2002). Okun's law revised: Should we worry about low unemployment? Public Administration and Public Policy, 97, 135-142.

Aranki, T., Friberg, K., \& Sjödin, M. (2010, March 31). The relationship between the business cycle and the labour market in Sweden. Sveriges Riksbank, No. 2.

Arbettslöshetsrapporten. (2013). Akademikeernas a- kassa report. Sweden.

Black, F. (1987). Business cycle and equilibrium. Oxford: Basil Blackwell.

Breusch, T. S. (1978). Testing for autocorrelation in dynamic linear models. Australian Economic Papers, 17, 334-355. http://dx.doi.org/10.1111/j.1467-8454.1978.tb00635.x

Cuaresma, J. C. (2003). Okun's law revisited. Oxford Bulletin of Economic and Statistics, 65(4), 439-51. http://dx.doi.org/10.1111/1468-0084.t01-1-00056

Dickey, D. A., \& Fuller, W. A. (1979). Distribution of the estimators for autoregressive time series with a unit root. Journal of the American Statistical Association, 74, 427-431.

Dickey, D. A., \& Fuller, W. A. (1981). The likelihood ratio statistics for autoregressive time series with a unit root. Econometrica, 49(4), 1057-1072. http://dx.doi.org/10.2307/1912517 
Engle, R. F. (1982). Autoregressive conditional heteroscedasticity with estimates of variance of United Kingdom inflation. Econometrica, 50, 987-1008. http://dx.doi.org/10.2307/1912773

Fallon, P. R., \& Lucas, R. B. (2002). The impact of financial crises on the labour market, house hold incomes, and poverty. The World Bank Research Observer, 7(1), 21-45. http://dx.doi.org/10.1093/wbro/17.1.21

Godfrey, L. G. (1978). Testing for higher order serial correlation in regression equations when the regressors include lagged dependent variables. Econometrica, 46, 1303-1310. http://dx.doi.org/10.2307/1913830

Granger, C. W. J. (1969). Investigating causal relations by econometric models a cross-spectral method. Econometrica, 37, 24-36. http://dx.doi.org/10.2307/1912791

International Monetary Fund. (2010, April). Unemployment dynamics during recessions and recoveries: Okun's law and beyond. World Economic Outlook, Chapter 3.

Jarque, C. M., \& Bera, A. K. (1987). A test for normality of observations and regression residuals. International Statistical Review, 55, 163-172.

Johansen, S. (1988). Statistical analysis of cointegration vectors. Journal of Economic Dynamics and Control, 12, 231-254. http://dx.doi.org/10.1016/0165-1889(88)90041-3

Knotek II, E. S. (2007). How useful is Okun's law (pp. 73-103). Economic Review, Federal Reserve Bank of Kansas City, Issue QIV. Retrieved from http://www.kansascityfed.org/

Lee, J. M. (2000). The robustness of Okun's law: Evidence from OECD countries. Journal of Macroeconomics, 22(2), 331-356. http://dx.doi.org/10.1016/S0164-0704(00)00135-X

Moosa, I. A. (1997). A cross-country comparison of Okun's coefficient. Journal of Comparative Economics, 24(3), 335-356. http://dx.doi.org/10.1006/jcec.1997.1433

Okun, A. M. (1962). Potential GNP: Its measurement and significance (pp. 89-104). Proceedings of the Business and Economics Statistics Section of the American Statistical Association.

Olivier, B., Alessia, A., \& Francesco, G. (2013). Macroeconomics a European perspective (2nd ed.). London, UK: Pearson Education Limited.

Organisation for Economic Co-operation and Development (OECD). (2010). Tax-benefit models. OECD: Author. Retrieved from http://www.oecd./els/benefitsandwagesstatistics

Organisation for Economic Co-operation and Development (OECD). (2010). Benefits and wages. OECD: Author. Retrieved from http://www.oecd.org/els/social/workincentives

Padalino, S., \& Vivarelli, M. (1997). The employment of economic growth in the G-7 countries. International Labour Review, 136(2), 191-213.

Piacentini, P., \& Pini, P. (1998). Growth, productivity and employment: Do income distribution and internal components of demand matter? Retrieved from http://www.memo-europe.uni-bremen.de/doenloads/tnpini2.pdf

Pianta, M., Evangelista, R., \& Perani, G. (1996). The dynamics of innovation and employment: An international comparison. Science Technology Industry Review, 18, 67-93.

Prachowny, M. F. J. (1993). Okun's law: Theoretical foundations and revised estimates. Review of Economics and Statistics, 75(2), 331-335. http://dx.doi.org/10.2307/2109440

Romer, D. (2012). Advance macroeconomics (4th ed.). MCGraw-Hill Irwin.

Salman, A. K. (2012). Testing the causal nexus between output and unemployment: Swedish data. International Business Research, 5(10). http://dx.doi.org/10.5539/ibr.v5n10p29

Schwarz, G. (1978). Estimation the dimension of a model. Annals of Statistics, 6, 461-464. http://dx.doi.org/10.1214/aos/1176344136

Silvapulle, P., Moosa, I. A., \& Silvapulle, J. (2004). Asymmetry in Okuns's law. Canadian Journal of Economics, 37(2), 353-74. http://dx.doi.org/10.1111/j.0008-4085.2004.00006.x

Sorensen, P., \& Whitta, J. H. (2010). Introducing advanced macroeconomics, growth and Business cycles (2nd. ed.). McGraw- Hill, Higher Education.

The Organisation for Economic Co-operation and Development (OECD). (2011). Database.

White, H. (1980). A hetroskedasticity-consistent covariance matrix estimator and a direct test for 
heteroskedastisity. Econometrica, 48, 817-838. http://dx.doi.org/10.2307/1912934

\section{Notes}

Note 1. Arthur Okun was advisor to President Kennedy in the 1960s. Okun's law is, of course, not a law but an empirical regularity.

Note 2. In Europe, the replacement rate - which is computed as the fraction of the last wage which the social security administration provides to a person if he or she no longer works (and are called non replacement rates) varies across countries, and within each country, basically according to the type of household (single person or couple with children) and the sectors of industry. See OECD indicators (2010).

Note 3. Another aspect of unemployment insurance that is likely to affect wages is the duration of unemployment benefits, i.e. the number of months benefits are provided for the social security administration. At a given unemployment rate, a longer duration of unemployment benefit increases the wage in Europe, the duration of unemployment insurance varies a lot across countries, much more than the level of the benefit provided. In Europe, the duration of unemployment insurance varies a lot between countries, much more than the level of the benefits provided. In most of the countries, unemployment benefits are granted for less than one year, with the noteworthy exceptions of Belgium, where the benefits are unlimited, and of Denmark and the Netherlands where benefits are paid for 30 to 36 months maximum. See OECD indicators (2010), and see also David Romer (2012).

Note 4. The statistics indicators showed that the percentage of the unemployment for women (aged 15-74 years) in Finland was lower than the percentage of unemployment for men (Arbettslöshetsrapporten, 2013, Akademikeernas a- kassa, Stockholm, Sweden).

\section{Appendix A}

Table A1. Results of ADF test for unit root to the GDP cycle

\begin{tabular}{cccc}
\hline ADF Test Statistic & -2.923754 & $1 \%$ Critical Value* & -3.5312 \\
\hline & & $5 \%$ Critical Value & -2.9055 \\
& $10 \%$ Critical Value & -2.5899 \\
\hline
\end{tabular}

Note. *MacKinnon critical values for rejection of hypothesis of a unit root.

Table A2. ADF test for Unit root total unemployment

\begin{tabular}{cccc}
\hline ADF Test Statistic & -1.752588 & $1 \%$ Critical Value* & -3.5312 \\
\hline & & $5 \%$ Critical Value & -2.9055 \\
& & $10 \%$ Critical Value & -2.5899 \\
\hline
\end{tabular}

Note. *MacKinnon critical values for rejection of hypothesis of a unit root.

Table A3. Results of ADF test for unit root male unemployment

\begin{tabular}{cccc}
\hline ADF Test Statistic & -2.126193 & $1 \%$ Critical Value* & -3.5312 \\
\hline & & $5 \%$ Critical Value & -2.9055 \\
& & $10 \%$ Critical Value & -2.5899 \\
\hline
\end{tabular}

Note. *MacKinnon critical values for rejection of hypothesis of a unit root.

Table A4. Results of ADF test for unit root female unemployment

\begin{tabular}{cccc}
\hline ADF Test Statistic & -1.409264 & $1 \%$ Critical Value* & -3.5312 \\
\hline & & $5 \%$ Critical Value & -2.9055 \\
& & $10 \%$ Critical Value & -2.5899
\end{tabular}

Note. *MacKinnon critical values for rejection of hypothesis of a unit root. 


\section{Appendix B}

Table B1. The cointegration regression results for total unemployment

\begin{tabular}{|c|c|c|}
\hline \multicolumn{3}{|c|}{ Date: $09 / 22 / 13$ Time: $23: 55$} \\
\hline \multicolumn{3}{|c|}{ Sample: 1 - 66} \\
\hline \multicolumn{3}{|c|}{ Included observations: 66} \\
\hline \multicolumn{3}{|c|}{ Standard errors \& $\mathrm{t}$-statistics in parentheses } \\
\hline Independent variables & GDP_F & UN_F_TOT \\
\hline GDP_F(-1) & 0.785450 & -0.037340 \\
\hline $\mathrm{Se}$ & $(0.13340)$ & $(0.01059)$ \\
\hline T-test & $(5.88782)$ & $(-3.52651)$ \\
\hline GDP_F(-2) & 0.008460 & 0.021729 \\
\hline $\mathrm{Se}$ & $(0.17382)$ & $(0.01380)$ \\
\hline T-test & $(0.04867)$ & $(1.57494)$ \\
\hline GDP_F(-3) & -0.267393 & $3.26 \mathrm{E}-05$ \\
\hline $\mathrm{Se}$ & $(0.12695)$ & $(0.01008)$ \\
\hline T-test & $(-2.10621)$ & $(0.00323)$ \\
\hline UN_F_TOT(-1) & -2.118661 & 1.753504 \\
\hline $\mathrm{Se}$ & $(1.55831)$ & $(0.12369)$ \\
\hline T-test & $(-1.35959)$ & $(14.1769)$ \\
\hline UN_F_TOT(-2) & 0.801119 & -1.121755 \\
\hline $\mathrm{Se}$ & $(2.69758)$ & $(0.21411)$ \\
\hline T-test & $(0.29698)$ & $(-5.23906)$ \\
\hline UN_F_TOT(-3) & 1.362961 & 0.349388 \\
\hline $\mathrm{Se}$ & $(1.55243)$ & $(0.12322)$ \\
\hline T-test & $(0.87795)$ & $(2.83547)$ \\
\hline $\mathrm{C}$ & 0.447750 & 0.165007 \\
\hline $\mathrm{Se}$ & $(0.95372)$ & $(0.07570)$ \\
\hline T-test & $(0.46948)$ & $(2.17978)$ \\
\hline R-squared & 0.771319 & 0.997194 \\
\hline Adj. R-squared & 0.748063 & 0.996909 \\
\hline Sum sq. resids & 195.6647 & 1.232690 \\
\hline S.E. equation & 1.821085 & 0.144544 \\
\hline F-statistic & 33.16680 & 3494.877 \\
\hline Log likelihood & -129.5126 & 37.70512 \\
\hline Akaike AIC & 4.136746 & -0.930458 \\
\hline Schwarz SC & 4.368982 & -0.698222 \\
\hline Mean dependent & 2.975758 & 9.819697 \\
\hline S.D. dependent & 3.628140 & 2.599835 \\
\hline Determinant Residual & & 0.046628 \\
\hline Log Likelihood & & -86.13653 \\
\hline Akaike Information $\mathrm{Cr}$ & & 3.034440 \\
\hline Schwarz Criteria & & 3.498913 \\
\hline
\end{tabular}

Table B2. The cointegration regression results for male unemployment

\begin{tabular}{|c|c|c|}
\hline \multirow{2}{*}{\multicolumn{3}{|c|}{$\begin{array}{l}\text { Date: 09/23/13 } \\
\text { Sample: } 1 \text { - } 66\end{array}$}} \\
\hline & & \\
\hline \multicolumn{3}{|c|}{ Included observations: 66} \\
\hline \multicolumn{3}{|c|}{ Standard errors \& t-statistics in parentheses } \\
\hline Independent variables & GDP_F & UN_F_M \\
\hline GDP_F(-1) & 0.797448 & -0.054828 \\
\hline $\mathrm{Se}$ & $(0.13119)$ & $(0.01427)$ \\
\hline T-test & $(6.07876)$ & $(-3.84289)$ \\
\hline GDP_F(-2) & 0.013863 & 0.022885 \\
\hline $\mathrm{Se}$ & $(0.17388)$ & $(0.01891)$ \\
\hline T-test & $(0.07973)$ & $(1.21018)$ \\
\hline
\end{tabular}




\begin{tabular}{|c|c|c|}
\hline GDP_F(-3) & -0.248925 & 0.007983 \\
\hline $\mathrm{Se}$ & $(0.12778)$ & $(0.01390)$ \\
\hline T-test & $(-1.94807)$ & $(0.57442)$ \\
\hline UN_F_M(-1) & -1.656754 & 1.760278 \\
\hline $\mathrm{Se}$ & $(1.05718)$ & $(0.11498)$ \\
\hline T-test & $(-1.56715)$ & (15.3101) \\
\hline UN_F_M(-2) & 0.977368 & -1.219695 \\
\hline $\mathrm{Se}$ & $(1.82096)$ & $(0.19804)$ \\
\hline T-test & $(0.53673)$ & $(-6.15878)$ \\
\hline UN_F_M(-3) & 0.671252 & 0.425014 \\
\hline $\mathrm{Se}$ & (1.03354) & $(0.11240)$ \\
\hline T-test & $(0.64947)$ & $(3.78112)$ \\
\hline $\mathrm{C}$ & 0.987117 & 0.327529 \\
\hline $\mathrm{Se}$ & $(0.98254)$ & $(0.10686)$ \\
\hline T-test & $(1.00465)$ & $(3.06508)$ \\
\hline R-squared & 0.770769 & 0.995004 \\
\hline Adj. R-squared & 0.747457 & 0.994496 \\
\hline Sum sq. resids & 196.1352 & 2.319902 \\
\hline S. E. equation & 1.823273 & 0.198294 \\
\hline F-statistic & 33.06366 & 1958.299 \\
\hline Log likelihood & -129.5919 & 16.83834 \\
\hline Akaike AIC & 4.139148 & -0.298131 \\
\hline Schwarz SC & 4.371384 & -0.065895 \\
\hline Mean dependent & 2.975758 & 9.707576 \\
\hline S.D. dependent & 3.628140 & 2.672729 \\
\hline \multicolumn{2}{|c|}{ Determinant Residual Covariance } & 0.095138 \\
\hline \multicolumn{2}{|c|}{ Log Likelihood } & -109.6697 \\
\hline \multicolumn{2}{|c|}{ Akaike Information Criteria } & 3.747567 \\
\hline \multicolumn{2}{|c|}{ Schwarz Criteria } & 4.212039 \\
\hline
\end{tabular}

Table B3. The cointegration regression results for female unemployment

\begin{tabular}{|c|c|c|}
\hline \multicolumn{3}{|c|}{ Date: 09/23/13 Time: $22: 50$} \\
\hline \multicolumn{3}{|c|}{ Sample: 1 - 66} \\
\hline \multicolumn{3}{|c|}{ Included observations: 66} \\
\hline \multicolumn{3}{|c|}{ Standard errors \& t-statistics in parentheses } \\
\hline Independent variables & GDP_F & UN_F_FE \\
\hline GDP_F(-1) & 0.916180 & -0.011910 \\
\hline $\mathrm{Se}$ & $(0.12909)$ & $(0.00899)$ \\
\hline T-test & $(7.09717)$ & $(-1.32485)$ \\
\hline GDP_F(-2) & -0.256076 & 0.010566 \\
\hline $\mathrm{Se}$ & $(0.12038)$ & $(0.00838)$ \\
\hline T-test & $(-2.12730)$ & $(1.26042)$ \\
\hline UN_F_FE(-1) & -2.853018 & 1.661931 \\
\hline $\mathrm{Se}$ & $(1.52303)$ & $(0.10606)$ \\
\hline T-test & $(-1.87326)$ & $(15.6695)$ \\
\hline UN_F_FE(-2) & 2.991963 & -0.670652 \\
\hline $\mathrm{Se}$ & $(1.51766)$ & $(0.10569)$ \\
\hline T-test & $(1.97144)$ & $(-6.34562)$ \\
\hline $\mathrm{C}$ & -0.742996 & 0.059096 \\
\hline $\mathrm{Se}$ & $(0.94188)$ & $(0.06559)$ \\
\hline T-test & $(-0.78884)$ & $(0.90098)$ \\
\hline R-squared & 0.740455 & 0.997507 \\
\hline Adj. R-squared & 0.723436 & 0.997344 \\
\hline Sum sq. resids & 222.0719 & 1.076947 \\
\hline S.E. equation & 1.908016 & 0.132872 \\
\hline
\end{tabular}




\begin{tabular}{lcc}
\hline F-statistic & 43.50675 & 6102.370 \\
Log likelihood & -133.6904 & 42.16236 \\
Akaike AIC & 4.202739 & -1.126132 \\
Schwarz SC & 4.368622 & -0.960249 \\
Mean dependent & 2.975758 & 9.931818 \\
S.D. dependent & 3.628140 & 2.578083 \\
Determinant Residual Covariance & & 0.051315 \\
Log Likelihood & & -89.29718 \\
Akaike Information Criteria & & 3.009005 \\
Schwarz Criteria & & 3.340771 \\
\hline
\end{tabular}

\section{Appendix C}

Table C1. Johansen's test for cointegration results of diagnostic tests GDP cycle and total unemployment VAR (3) model. Series GDP cycle and total Unemployment

\begin{tabular}{ccccc}
\hline Lags interval: 1 to 4 & & & & \\
& Likelihood & 5 Percent & 1 Percent & Hypothesized \\
\hline Eigenvalue & Ratio & Critical Value & Critical Value & No. of CE(s) \\
0.275666 & 27.19971 & 15.41 & 20.04 & None ** \\
0.085716 & 5.914508 & 3.76 & 6.65 & At most $1 *$ \\
\hline
\end{tabular}

Note. Johansen's test for cointegration shows that these variables are cointegrated.

Table C1a. Single Equation regression of Total Unemployment on GDP cycle

\begin{tabular}{lllll}
\hline $\begin{array}{l}\text { Dependent Variable: UN_F_TOT } \\
\text { Method: Least Squares } \\
\text { Date: } 09 / 23 / 13 \quad \text { Time: 00:08 } \\
\text { Sample: } 1-66\end{array}$ & & & \\
Included observations: 66 & & & & \\
\hline Variable & Coefficient & Std. Error & t-Statistic & Prob. \\
\hline GDP_F(-1) & -0.033853 & 0.010789 & -3.137689 & 0.0026 \\
GDP_F(-2) & 0.024308 & 0.014169 & 1.715566 & 0.0914 \\
GDP_F(-3) & $-4.71 \mathrm{E}-05$ & 0.010387 & -0.004539 & 0.9964 \\
UN_F_TOT(-1) & 1.829861 & 0.122275 & 14.96507 & 0.0000 \\
UN_F_TOT(-2) & -1.132956 & 0.220643 & -5.134801 & 0.0000 \\
UN_F_TOT(-3) & 0.299662 & 0.124819 & 2.400780 & 0.0195 \\
R-squared & 0.996968 & Mean dependent var & 9.819697 \\
Adjusted R-squared & 0.996716 & S.D. dependent var & 2.599835 \\
S.E. of regression & 0.148994 & Akaike info criterion & -0.883307 \\
Sum squared resid & 1.331961 & Schwarz criterion & -0.684247 \\
Log likelihood & 35.14913 & F-statistic & 3946.172 \\
Durbin-Watson stat & 1.947205 & Prob(F-statistic) & & 0.000000 \\
\hline
\end{tabular}

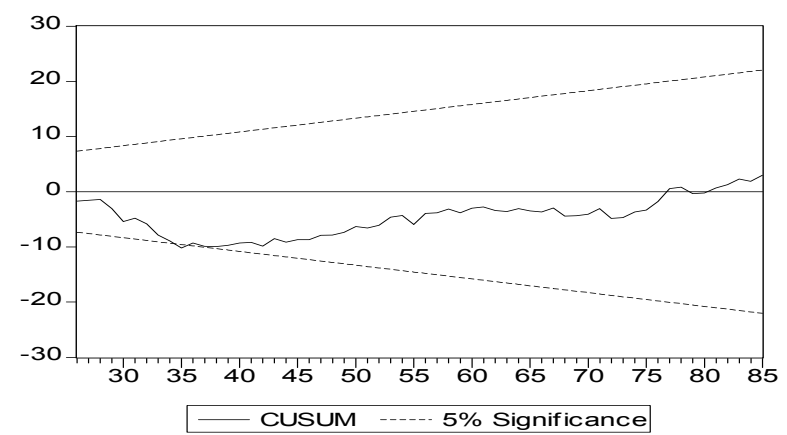

Figure C1a. Diagnostic tests 
Table C1b. The CUSUM test for possible structural breaks

\begin{tabular}{llll}
\hline Ramsey RESET Test: & & & \\
\hline F-statistic & 3.207612 & Probability & 0.078426 \\
Log likelihood ratio & 3.494035 & Probability & 0.061590 \\
\hline
\end{tabular}
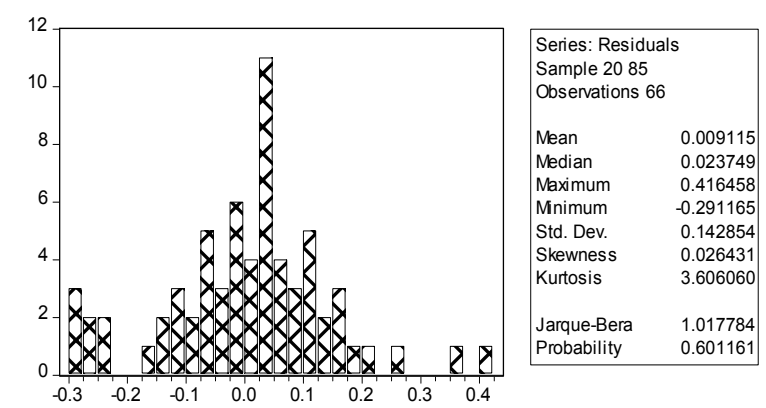

Figure $\mathrm{Clb}$. The RESET test for functional misspecificatio

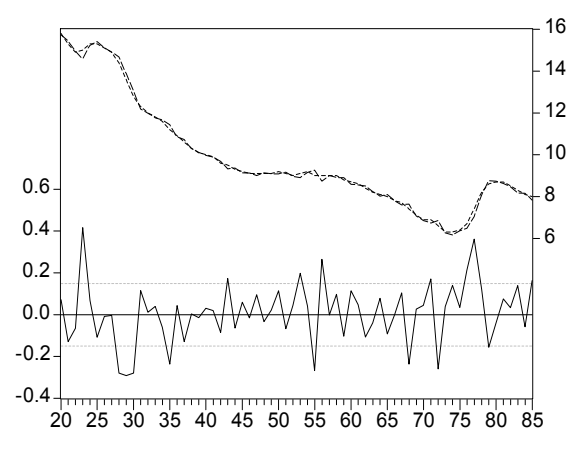

- Residual ------ Actual ----- Fitted

Figure C1c. Jarque-Bera test for non-normality of the error term

Breusch-Godfrey Serial Correlation LM test

\begin{tabular}{llll}
\hline F-statistic & 0.068205 & Probability & 0.794878 \\
Obs*R-squared & 0.000000 & Probability & 1.000000 \\
\hline
\end{tabular}

ARCH test

\begin{tabular}{llll}
\hline F-statistic & 0.647530 & Probability & 0.424024 \\
Obs*R-squared & 0.661289 & Probability & 0.416105 \\
\hline
\end{tabular}

White Heteroskedasticity test

\begin{tabular}{llll}
\hline F-statistic & 0.739152 & Probability & 0.792114 \\
Obs*R-squared & 22.72661 & Probability & 0.699609 \\
\hline
\end{tabular}

Single equation regression of GDP cycle on total unemployment

\begin{tabular}{lllll}
\hline $\begin{array}{l}\text { Dependent Variable: GDP_F } \\
\text { Method: Least Squares }\end{array}$ & & & \\
Date: 09/23/13 Time: 00:12 & & & & \\
Sample: 1 - 66 & & & & \\
Included observations: 66 & & & & \\
\hline Variable & Coefficient & Std. Error & t-Statistic & Prob. \\
\hline GDP_F(-1) & 0.794913 & 0.131012 & 6.067500 & 0.0000 \\
GDP_F(-2) & 0.015458 & 0.172055 & 0.089846 & 0.9287 \\
\hline
\end{tabular}




\begin{tabular}{lllll}
\hline GDP_F(-3) & -0.267609 & 0.126126 & -2.121760 & 0.0380 \\
UN_F_TOT(-1) & -1.911467 & 1.484771 & -1.287382 & 0.2029 \\
UN_F_TOT(-2) & 0.770726 & 2.679227 & 0.287667 & 0.7746 \\
UN_F_TOT(-3) & 1.228029 & 1.515652 & 0.810232 & 0.4210 \\
R-squared & 0.770464 & Mean dependent var & 2.975758 \\
Adjusted R-squared & 0.751336 & S.D. dependent var & 3.628140 \\
S.E. of regression & 1.809216 & Akaike info criterion & 4.110172 \\
Sum squared resid & 196.3957 & Schwarz criterion & 4.309231 \\
Log likelihood & -129.6357 & F-statistic & 40.27944 \\
Durbin-Watson stat & 2.061131 & Prob(F-statistic) & 0.000000 \\
\hline
\end{tabular}
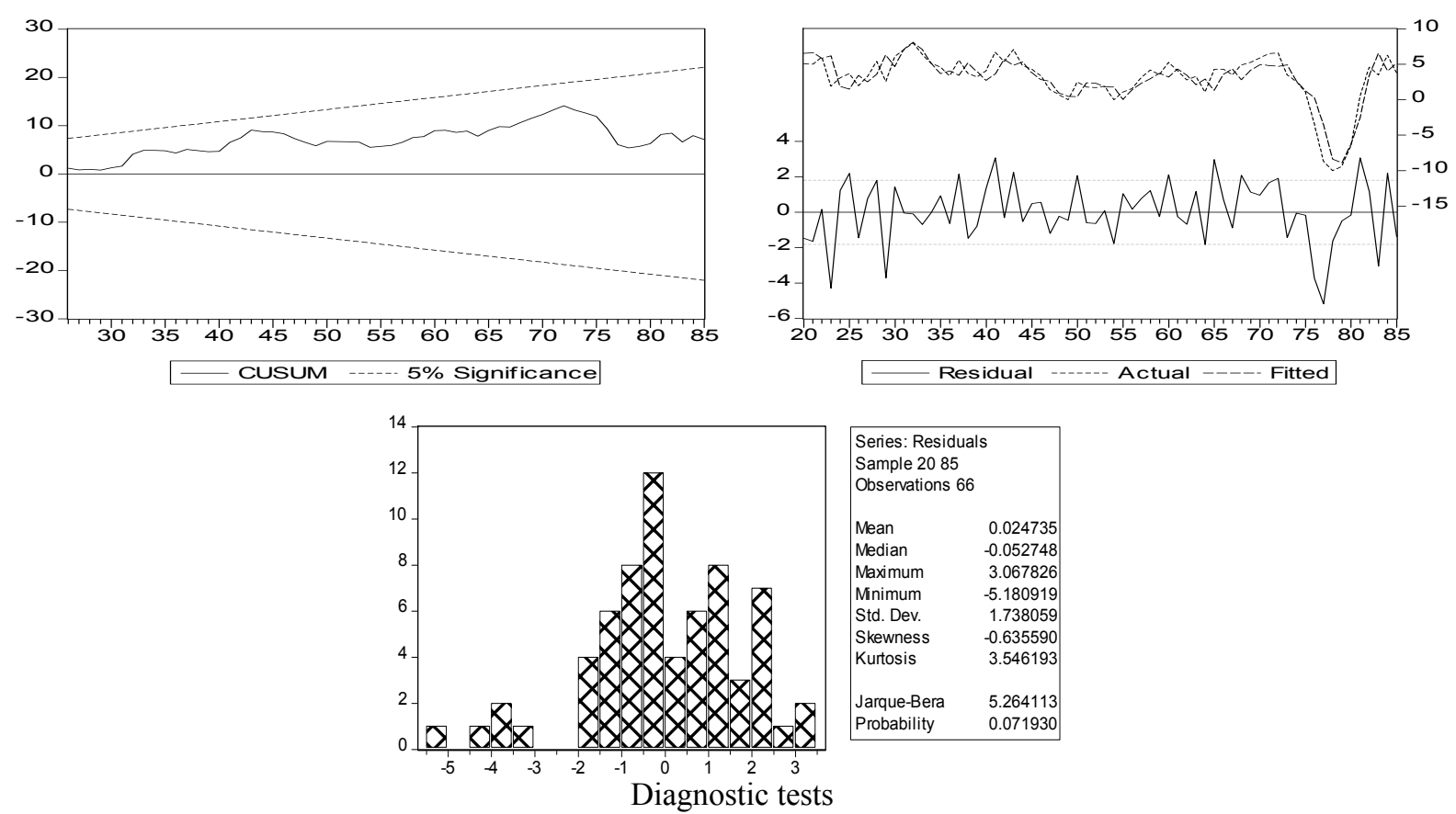

\begin{tabular}{lll}
\hline Breusch-Godfrey Serial Correlation LM Test: & \\
\hline F-statistic & 1.470984 Probability & 0.230024 \\
Obs*R-squared & 1.592238 Probability & 0.207007 \\
\hline ARCH Test: & & 0.315321 \\
\hline F-statistic & 1.024519 Probability & 0.307792 \\
\hline Obs*R-squared & 1.040129 Probability & \\
\hline Ramsey RESET Test: & & 0.012069 \\
F-statistic & 6.708532 Probability & 0.007676 \\
Log likelihood ratio & 7.107628 Probability & 0.208615 \\
White Heteroskedasticity Test: & & 0.231552 \\
\hline F-statistic & 1.325774 Probability & \\
Obs*R-squared & 32.01437 Probability &
\end{tabular}

Table C2. Johansen's test for cointegration results of diagnostic tests GDP cycle and male unemployment VAR(3) model. Series GDP cycle and male Unemployment 
Lags interval: 1 to 4

\begin{tabular}{|c|c|c|c|c|}
\hline Eigenvalue & $\begin{array}{l}\text { Likelihood } \\
\text { Ratio }\end{array}$ & $\begin{array}{l}5 \text { Percent } \\
\text { Critical Value }\end{array}$ & $\begin{array}{l}1 \text { Percent } \\
\text { Critical Value }\end{array}$ & $\begin{array}{l}\text { Hypothesized } \\
\text { No. of } \mathrm{CE}(\mathrm{s})\end{array}$ \\
\hline 0.276583 & 28.94482 & 15.41 & 20.04 & None $* *$ \\
\hline 0.108446 & 7.576056 & 3.76 & 6.65 & At most $1 * *$ \\
\hline
\end{tabular}

Note: Johansen's test for cointegration shows that these variables are cointegrated.

Single equation regression of unemployment (male) on GDP cycle

\begin{tabular}{|c|c|c|c|c|}
\hline \multicolumn{5}{|c|}{ Dependent Variable: UN_F_M } \\
\hline \multicolumn{5}{|c|}{ Method: Least Squares } \\
\hline Date: $09 / 23 / 13 \quad \mathrm{Ti}$ & \multicolumn{4}{|c|}{ Time: $22: 28$} \\
\hline \multicolumn{5}{|l|}{ Sample: 1 - 66} \\
\hline \multicolumn{5}{|c|}{ Included observations: 66} \\
\hline Variable & Coefficient & Std. Error & $\mathrm{t}$-Statistic & Prob. \\
\hline GDP_F(-1) & -0.045956 & 0.014916 & -3.080959 & 0.0031 \\
\hline GDP_F(-2) & 0.028198 & 0.020105 & 1.402534 & 0.1659 \\
\hline GDP_F(-3) & 0.009168 & 0.014832 & 0.618161 & 0.5388 \\
\hline UN_F_M(-1) & 1.879545 & 0.115512 & 16.27148 & 0.0000 \\
\hline UN_F_M(-2) & -1.225166 & 0.211434 & -5.794557 & 0.0000 \\
\hline UN_F_M(-3) & 0.340979 & 0.116386 & 2.929740 & 0.0048 \\
\hline R-squared & 0.994208 & \multicolumn{2}{|c|}{ Mean dependent var } & 9.707576 \\
\hline Adjusted R-squared & 0.993726 & \multicolumn{2}{|c|}{ S.D. dependent var } & 2.672729 \\
\hline S.E. of regression & 0.211711 & \multicolumn{2}{|c|}{ Akaike info criterion } & -0.180677 \\
\hline Sum squared resid & 2.689305 & \multicolumn{2}{|c|}{ Schwarz criterion } & 0.018383 \\
\hline Log likelihood & 11.96233 & \multicolumn{2}{|l|}{ F-statistic } & 2059.879 \\
\hline Durbin-Watson stat & 1.927478 & \multicolumn{2}{|c|}{ Prob(F-statistic) } & 0.000000 \\
\hline
\end{tabular}
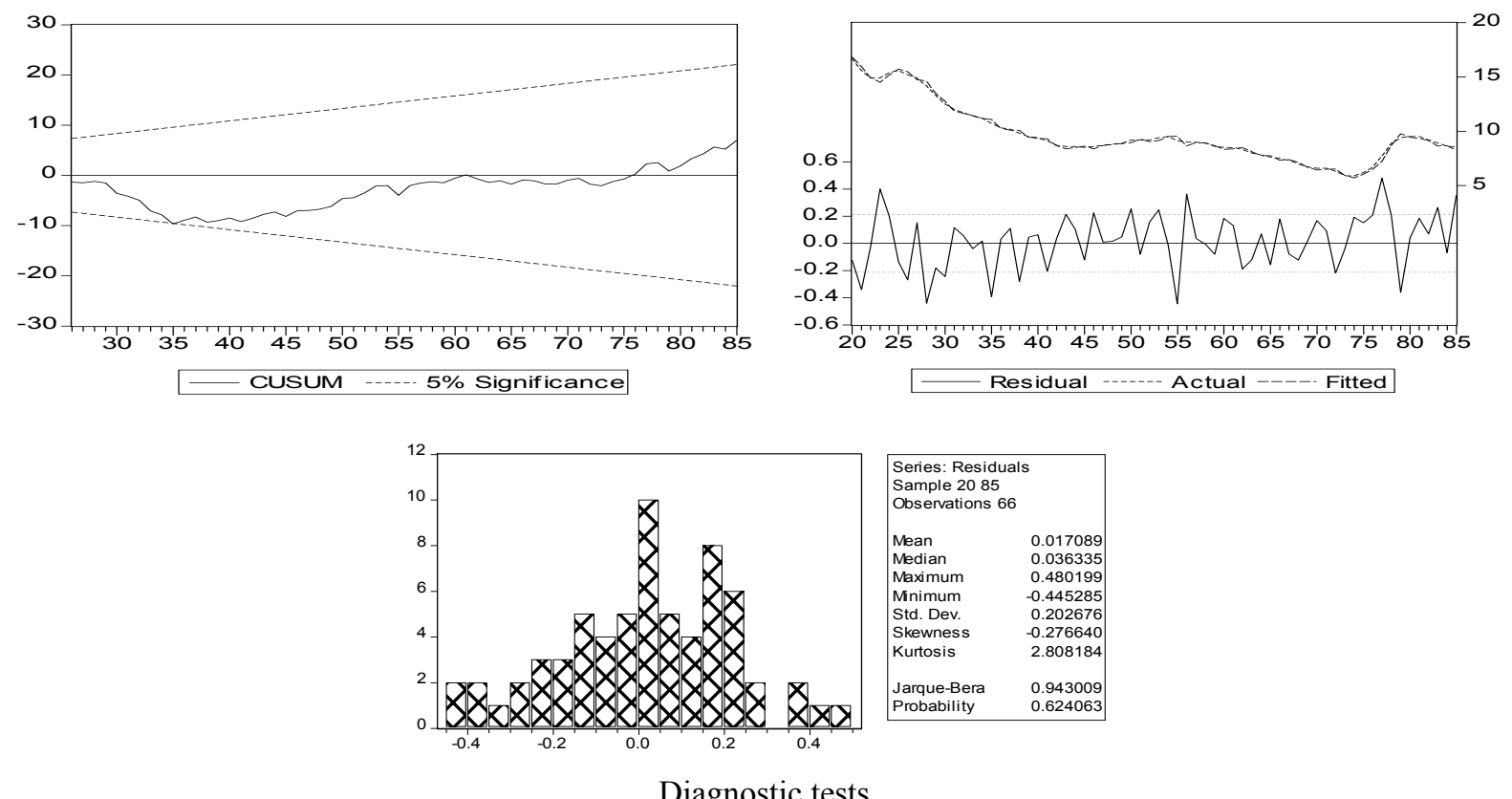

Diagnostic tests

Breusch-Godfrey Serial Correlation LM test

\begin{tabular}{llll}
\hline F-statistic & 0.025690 & Probability & 0.873207 \\
\hline Obs*R-squared & 0.000000 & Probability & 1.000000 \\
\hline
\end{tabular}


ARCH test

\begin{tabular}{llll}
\hline F-statistic & 0.399860 & Probability & 0.529450 \\
\hline Obs*R-squared & 0.409952 & Probability & 0.521994 \\
\hline
\end{tabular}

White Heteroskedasticity test

\begin{tabular}{llll}
\hline F-statistic & 0.958397 & Probability & 0.539087 \\
\hline Obs*R-squared & 26.73687 & Probability & 0.478059 \\
\hline
\end{tabular}

Ramsey RESET test

\begin{tabular}{llll}
\hline F-statistic & 3.194401 & Probability & 0.030181 \\
\hline Log likelihood ratio & 10.25647 & Probability & 0.016507 \\
\hline
\end{tabular}

Single Equation regression of GDP cycle on Unemployment (male)

Dependent Variable: GDP_F

Method: Least Squares

Date: 09/23/13 Time: 23:11

Sample: 1 - 66

Included observations: 66

\begin{tabular}{lllll}
\hline Variable & Coefficient & Std. Error & t-Statistic & Prob. \\
\hline GDP_F(-1) & 0.824188 & 0.128467 & 6.415539 & 0.0000 \\
GDP_F(-2) & 0.029876 & 0.173162 & 0.172531 & 0.8636 \\
GDP_F(-3) & -0.245352 & 0.127741 & -1.920699 & 0.0595 \\
UN_F_M(-1) & -1.297306 & 0.994871 & -1.303995 & 0.1972 \\
UN_F_M(-2) & 0.960879 & 1.821025 & 0.527658 & 0.5997 \\
UN_F_M(-3) & 0.417985 & 1.002398 & 0.416985 & 0.6782 \\
R-squared & 0.766847 & Mean dependent var & & 2.975758 \\
Adjusted R-squared & 0.747418 & S.D. dependent var & & 3.628140 \\
S.E. of regression & 1.823415 & Akaike info criterion & & 4.125807 \\
Sum squared resid & 199.4905 & Schwarz criterion & & 4.324867 \\
Log likelihood & -130.1516 & F-statistic & & 39.46839 \\
Durbin-Watson stat & 2.046823 & Prob(F-statistic) & & 0.000000 \\
\hline
\end{tabular}
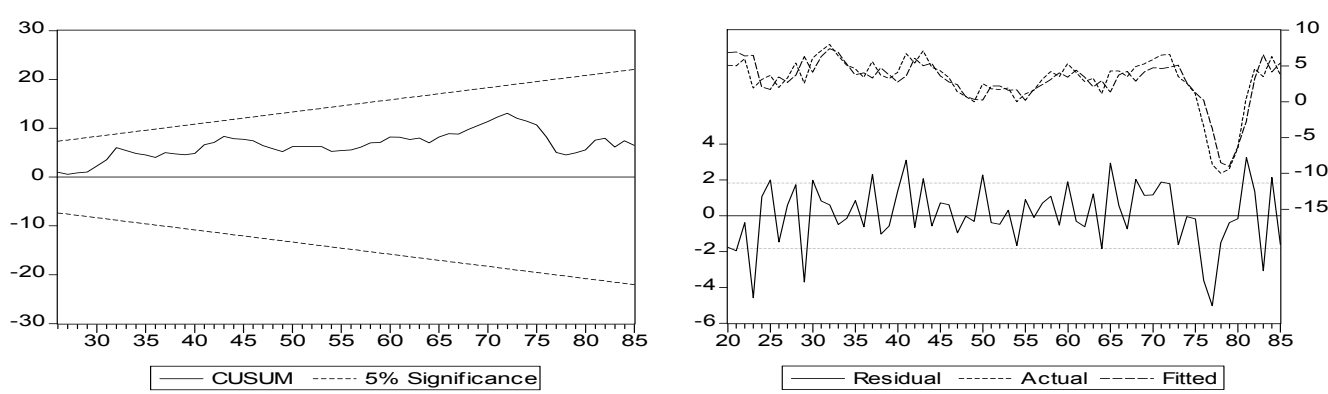

Diagnostic tests

Breusch-Godfrey Serial Correlation LM test

\begin{tabular}{llll}
\hline F-statistic & 1.456859 & Probability & 0.232248 \\
\hline Obs*R-squared & 1.533863 & Probability & 0.215534 \\
\hline
\end{tabular}

ARCH test

\begin{tabular}{llll}
\hline F-statistic & 0.654221 & Probability & 0.421652 \\
\hline Obs*R-squared & 0.668053 & Probability & 0.413731 \\
\hline
\end{tabular}


Ramsey RESET test

\begin{tabular}{llll}
\hline F-statistic & 6.486066 & Probability & 0.013501 \\
\hline Log likelihood ratio & 6.883797 & Probability & 0.008698 \\
\hline
\end{tabular}

White Heteroskedasticity test

\begin{tabular}{llll}
\hline F-statistic & 1.070050 & Probability & 0.403240 \\
\hline Obs*R-squared & 12.87169 & Probability & 0.378435 \\
\hline
\end{tabular}

Table C3. Johansen's test for cointegration results of diagnostic tests GDP cycle and female unemployment VAR(2) model. Series GDP cycle and female Unemployment

Lags interval: 1 to 4

\begin{tabular}{lllll}
\hline & Likelihood & 5 Percent & 1 Percent & Hypothesized \\
Eigenvalue & Ratio & Critical Value & Critical Value & No. of CE(s) \\
\hline 0.222298 & 18.86057 & 15.41 & 20.04 & None * \\
0.033771 & 2.267422 & 3.76 & 6.65 & At most 1 \\
\hline
\end{tabular}

Note: Johansen's test for cointegration shows that these variables are cointegrated.

Single Equation regression of female Unemployment on GDP cycle

\begin{tabular}{|c|c|c|c|c|}
\hline \multicolumn{5}{|c|}{ Dependent Variable: UN_F_FE } \\
\hline \multicolumn{5}{|c|}{ Method: Least Squares } \\
\hline Date: $09 / 23 / 13 \quad \mathrm{Ti}$ & \multicolumn{4}{|c|}{ Time: $22: 54$} \\
\hline \multicolumn{5}{|l|}{ Sample: 1 - 66} \\
\hline \multicolumn{5}{|c|}{ Included observations: 66} \\
\hline Variable & Coefficient & Std. Error & t-Statistic & Prob. \\
\hline GDP_F(-1) & -0.012357 & 0.008962 & -1.378749 & 0.1729 \\
\hline GDP_F(-2) & 0.010475 & 0.008369 & 1.251529 & 0.2154 \\
\hline UN_F_FE(-1) & 1.667499 & 0.105720 & 15.77271 & 0.0000 \\
\hline UN_F_FE(-2) & -0.670542 & 0.105527 & -6.354231 & 0.0000 \\
\hline R-squared & 0.997474 & \multicolumn{2}{|c|}{ Mean dependent var } & 9.931818 \\
\hline Adjusted R-squared & 0.997352 & \multicolumn{2}{|c|}{ S.D. dependent var } & 2.578083 \\
\hline S.E. of regression & 0.132670 & \multicolumn{2}{|c|}{ Akaike info criterion } & -1.143215 \\
\hline Sum squared resid & 1.091279 & \multicolumn{2}{|c|}{ Schwarz criterion } & -1.010509 \\
\hline Log likelihood & 41.72611 & \multicolumn{2}{|l|}{ F-statistic } & 8161.000 \\
\hline Durbin-Watson stat & 1.604959 & \multicolumn{2}{|c|}{ Prob(F-statistic) } & 0.000000 \\
\hline
\end{tabular}
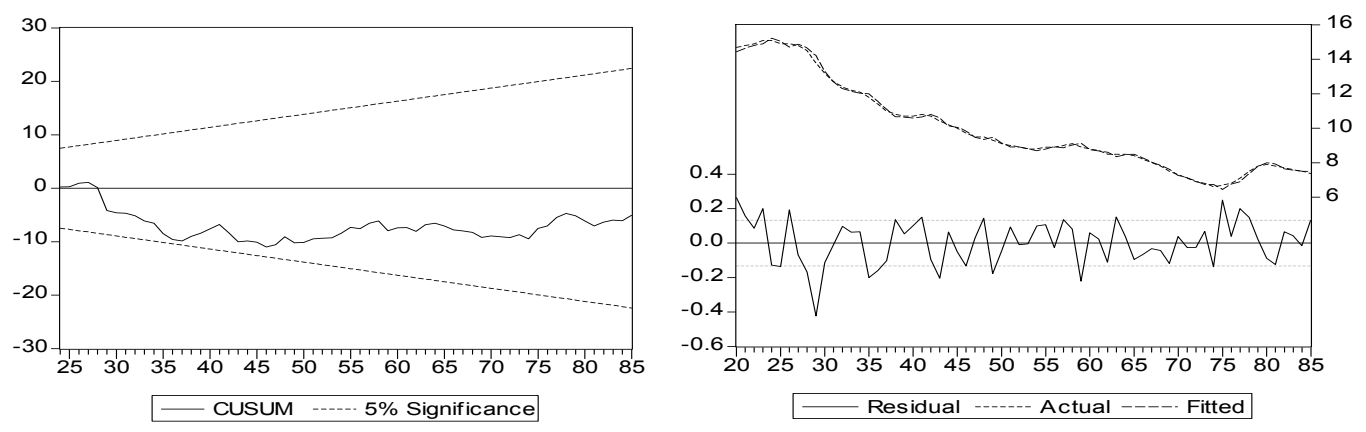

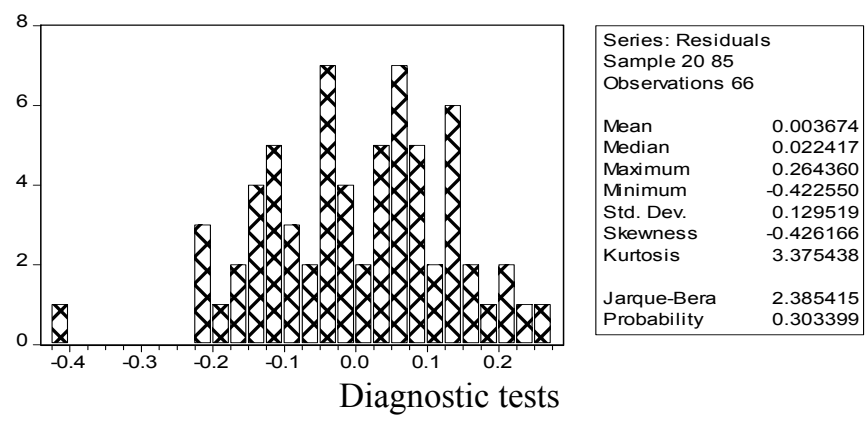

Jarque-Bera
Probability 0.303399

Breusch-Godfrey Serial Correlation LM test

\begin{tabular}{llll}
\hline F-statistic & 2.163567 & Probability & 0.123797 \\
\hline Obs*R-squared & 4.389355 & Probability & 0.111394 \\
\hline
\end{tabular}

ARCH test

\begin{tabular}{llll}
\hline F-statistic & 0.143268 & Probability & 0.706326 \\
\hline Obs*R-squared & 0.147481 & Probability & 0.700954 \\
\hline
\end{tabular}

Ramsey RESET test

\begin{tabular}{llll}
\hline F-statistic & 0.428664 & Probability & 0.515106 \\
\hline Log likelihood ratio & 0.462178 & Probability & 0.496608 \\
\hline
\end{tabular}

White Heteroskedasticity test

\begin{tabular}{llll}
\hline F-statistic & 1.800496 & Probability & 0.095884 \\
\hline Obs*R-squared & 13.31385 & Probability & 0.101497 \\
\hline
\end{tabular}

\section{Copyrights}

Copyright for this article is retained by the author(s), with first publication rights granted to the journal.

This is an open-access article distributed under the terms and conditions of the Creative Commons Attribution license (http://creativecommons.org/licenses/by/3.0/). 